\title{
Jornalismo e Crítica de Mídia
}

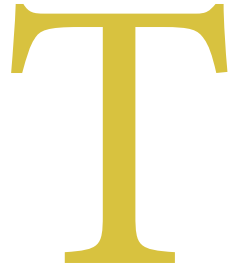

emos a satisfação de apresentar a primeira edição semestral de 2019, volume 16 da revista Estudos em Jornalismo e Mídia - EJM, com o dossiê especial sobre Jornalismo e Crítica de Mídia. A edição está composta por 14 artigos que integram o especial Apreciações culturais e políticas na crítica de mídia, além de quatro artigos de Temas Livres e uma entrevista. A apresentação do dossiê Apreciações culturais e políticas na crítica de mídia é assinada pelas editoras convidadas professora Gislene da Silva, colega do Departamento de Jornalismo e do Programa de Pós-Graduação em Jornalismo da Universidade Federal de Santa Catarina - PPGJOR-UFSC, em parceira com a professora Rosana de Lima Soares, livre-docente na Escola de Comunicações e Artes da Universidade de São Paulo - ECA-USP, atuando junto ao Departamento de Jornalismo e Editoração e ao Programa de Pós-Graduação em Meios e Processos Audiovisuais.

Na seção Temas Livres, esta edição da EJM traz o artigo As rotinas produtivas do coletivo Mídia Ninja: narrativas jornalísticas e midiativismo, de autoria de Leonel Azevedo de Aguiar (PUC-Rio) e Claudia Miranda Rodrigues (PUC-Rio). A partir do quadro teórico da agenda-setting e do newsmaking e de metodologia que mescla observação participante e análise de conteúdo, os pesquisadores identificam uma disputa de narrativas. Tal disputa, defendem os autores, se expressa em tentativas de desconstrução do discurso jornalístico do polo empresarial do Jornalismo e por questionamentos de valores que regem o polo profissional deste campo.

No artigo Narratividade jornalística e a inferência das redes sociais na produção de conteúdo do portal de notícias HuffPost Brasil, Aline Tainá Amaral Horn (Universidade Lumière Lyon 2 - França) investiga o tratamento do conteúdo jornalístico na edição brasileira do pure player HuffPost sobre um caso de assédio sexual sofrido por uma jornalista, e o modo como as redes sociais serviram de matéria-prima para a produção das notícias na cobertura desse acontecimento. Da análise qualitativa das notícias, que se apoia na análise pragmática da narrativa jornalística, a pesquisadora conclui que a cobertura "enfatiza a indignação e rejeição da opinião pública sobre o caso, e que as campanhas nascidas nas redes sociais encadeiam ritmo à narrativa jornalística".

Paula de Souza Paes (UEMG) e Denise Cogo (ESPM-SP), por sua vez, analisam os obstáculos à presença de minorias, principalmente as de origem migratória, nas redações de jornais franceses no contexto das políticas públicas de regulação desenvolvidas pelo CSA (Conselho Superior de Audiovisual), as quais buscam impulsionar a diversidade étnico-cultural nos meios de comunicação. No estudo - intitulado Jornalismo e diversidade étnico-cultural no contexto francês: uma análise das políticas de regulação 
do Conselho Superior de Audiovisual -, as pesquisadoras realizam análise empírica desenvolvida em dois eixos. Um deles, aborda a percepção que os jornalistas têm sobre o tratamento da diversidade étnico-cultural, através de análise das atividades da Fundação Franco-Americana voltadas para a diversidade. O outro, aborda a presença dos jornalistas de origem imigrante nas redações, através de entrevistas semi-estruturadas com estes profissionais, os quais revelam "a tensão entre o imaginário social midiático e as políticas de apoio à diversidade”.

O quarto e último artigo da seção Temas Livres, intitulado Fake news e a falha da Folha de S. Paulo: visibilidade da crítica em casos de paródia e sátira jornalística, é assinado por Ivan Paganotti (FIAM-FAAM). O artigo trata do caso da remoção do site www.falhadespaulo.com.br, demandado judicialmente pelo jornal Folha de S. Paulo, em 2010 - site que imitava elementos da identidade visual do periódico para criticar seu noticiário. $\mathrm{O}$ pesquisador analisa como o conteúdo removido encontrou novos espaços online, dando ainda mais atenção para o que se procurava ocultar, e como o caso evidencia elementos da discussão sobre sites que imitam o jornalismo para a sua crítica.

Esta edição da EJM traz ainda uma entrevista com C.W. Anderson, professor e pesquisador norte-americano, atua na Universidade de Leeds, no Reino Unido. A entrevista foi realizada em fevereiro de 2019 por Lívia de Souza Vieira, doutora pelo PPGJOR-UFSC.

A edição é encerrada com a resenha "Um olhar feminista interseccional para subverter invisibilidades históricas", de Jéssica Gustafson, doutoranda no PPGJOR/UFSC, sobre o livro Cores e Contornos: Gênero e raça em revistas femininas do século 21, de autoria de Gabrielle Bittelbrun, que discute como gênero e raça se articulam e refletem visibilidades e apagamentos na construção do que é ser mulher em imagens e discursos na contemporaneidade.

Agradecemos a prestigiosa participação das editoras convidadas Gislene da Silva e Rosana Soares que apresentam na sequência o dossiê. Somos gratas também a todos (as) autores (as) que assinam os artigos, assim como a importante colaboração de nossa equipe de avaliadores (as) e de revisores (as) desta edição.

Ótima leitura!

Daiane Bertasso e Terezinha Silva 